\title{
INTERNATIONAL ENVIRONMENTAL LAW AND GLOBAL ENVIRONMENTAL GOVERNANCE: SOUTHERN INFLUENCES
}

\begin{tabular}{r|r}
\multicolumn{2}{c}{ Fernando Cardozo Fernandes Rei } \\
\hline Professor Associado do Doutorado em Direito Ambiental Internacional \\
da Universidade Católica de Santos \\
Professor Titular de Direito Ambiental da Fundação Armando Álvares Penteado-FAAP \\
Email: fernandorei@ig.com.br
\end{tabular}

\begin{abstract}
The purpose of this article when it discusses the southern approaches brought to global governance gets mixed with the addressing of the challenges facing the legal science in harmony with the others sciences to deal with the complex environmental issues of the 21st century. Thinking of a successful international environmental regulation is talking about an effort to understand the need for the instrumental law to comply with its role to solve complex issues that are typical of the construction of a sustainable society. The first part of the article consider that the international environmental law has been facing the emerging global environmental issues in an innovating way, incorporating a new form of global environmental governance based on which new players are brought to the discussion and implementation of measures to face environmental problems. After that, the article highlights the southern actions in the role of the scientific expertise and in the environmental paradiplomacy, and evaluates the influence and contributions in the decision making scenario and in the news perspectives of international law. The article concludes that the southern influences suggest a more pragmatic, finalistic international law that is concerned about the results, the achievement of the goals proposed.
\end{abstract}

Key-Words: international environmental law; paradiplomacy; IPCC; global environmental governance; southern influences. 


\title{
LEI AMBIENTAL INTERNACIONAL E GOVERNANÇA AMBIENTAL GLOBAL: INFLUÊECIAS DO SUL
}

\begin{abstract}
RESUMO
O objetivo deste artigo, ao discutir as abordagens do Sul trazidas à governança global, mescla-se ao embate dos desafios enfrentados pela ciência jurídica em harmonia com as outras ciências para lidar com as complexas questões ambientais do século XXI. Pensar em uma regulamentação ambiental internacional bem-sucedida é falar de um esforço para entender a necessidade de que a lei instrumental cumpra seu papel de resolver questões complexas típicas da construção de uma sociedade sustentável. A primeira parte do artigo considera que a lei ambiental internacional vem enfrentando as questões ambientais globais emergentes de maneira inovadora, incorporando uma nova forma de governança ambiental global com base na qual novos atores são levados à discussão e implementação de medidas para enfrentar as questões ambientais. Em seguida, o artigo destaca as ações do Sul no papel da expertise cientifica e na paradiplomacia ambiental, e avalia a influência e as contribuições no cenário decisório e nas novas perspectivas do direito internacional. O artigo conclui que as influências do Sul sugerem uma lei internacional mais pragmática e finalista que se preocupa com os resultados, a realização dos objetivos propostos.
\end{abstract}

Palavras-chave: direito ambiental internacional; paradiplomacia; IPCC; governança ambiental global; influências do sul. 


\section{INTRODUCTION}

More than $1100^{1}$ international environmental treaties have been adopted since the 1972 Stockholm Conference on the Human Environment first drew global attention to the dangers of transboundary pollution and rapid resource depletion. The elements of an international environmental treaty-making system have been pieced together, but it is fundamental to recognize that are inadequate ${ }^{2}$. The system produced treaties that inevitably fall short of their ambitious objectives.

In this system, there is no formal role for new international actors. There are no proceedings related to what countries must observe to ensure that their national and subnational laws conform to the agreements they have signed or what kinds of scientific evidence must be in hand to justify action.

The international scenario has been increasingly marked by certain instability in what regards the accomplishment of results. Such characteristic is a consequence of the nature of the international environment itself, and the complexity of international relations in a setting composed of actors and matters undergoing continuous transformation, which the $\mathrm{Law}^{3}$ and the diplomacy cannot ignore.

Moving on with this scenario or putting it into effect requires and delineates the pillars for a global governance model that calls for discussion and cooperation between academic and political actors, as well as new institutional arrangements. In fact, discuss the need for changes in attitudes, actors, and treaty-making arrangements required to lay a foundation for more effective environmental treaty making, from the perspective of the South.

The proposed southern strategy argues that the negotiating power of the South, which is essentially the power of coalition, can be still enhanced and make more effective through pre-negotiation consensus building. During international environmental negotiations developing countries have commonly employed a unified strategy through the G-77 and China (G-77/China). But also alone, some developing states, like China, India, Brazil, have had and have enough diplomatic capacity and

\footnotetext{
1 MITCHELL, Ronald. IEA Database Home. 2017.Available at: https://iea.uoregon.edu/. Access: Oct 2,2017

2 SUSSKIND, L.. Environmental Diplomacy. Oxford University Press. 2015

3 See BUANI, C.. A justiça de transição: ápice da internacionalização do direito? Revista de Direito Internacional, Brasília, v. 9, n. 4, 2012, p. 123-151.
} 
economic power to influence in many negotiations.

Assessing these global issues get more and more complicated and intricate as they arise in a context of a world that has long been problematic where attempts to solve real problems in an isolated fashion are inadequate, and as this biased and individualistic attitude is equivalent to confusing the symptoms of the disease with its own causes.

At the end of the past century, a phenomenon as central as the Cold War ceased to exist without being predicted by scholars of any school of thought, and in its wake, researchers and analysts started to focus their attention on a wide range of topics. These days, it is quite clear that such phenomena are related to complex changes and are inter-related in terms of technology, production and trade structure, financial flows, and safety and power relationships.

The tension and complexity that exists between technology, production, consumption, and the protection of the environment have aggravated. The failure of the UN Conference on Sustainable Development, also known as Rio+20, indicates that the structure and dynamics of the power relations in the contemporary world, particularly in the first years of the $21^{\text {st }}$ century, are less cooperative and less marked by unity of interests than those observed in the last decade of the previous century, post Rio$92^{4}$.

In fact, the Summit was unable to innovate so to adapt the global institutions to the evidences of planetary degradation and make them converge around making decisions towards the low-carbon, green economy,and to a society more and more vulnerable to abstract endangerments, beyond hazards ${ }^{5}$.

This failure is not limited to the Rio +20 , but it also suggests that, in the power relations of the contemporary world, there is not only less multilateral cooperation but also less room for paradigm changes and more possibilities for new (and well-known) confrontations, even in social and political contexts whose assessment is quite delicate.

At the same time, new fascist political movements threaten citizens from a disintegrating Europe and a fragmented Latin America to a polarized United States, and global governance seems nearly paralyzed ${ }^{6}$.

4 REI, F.C.F.. The Rio +20 in question. Revista Brasileira de Bioenergia, 14, p. 45, 2012.

5 BECK, Ulrich..Sociedade de risco: rumo a uma outra modernidade .São Paulo: Editora 34, 2010 , p. 10.

6 BARBER, Benjamin. Cool Cities: urban sovereignty and the fix for global warming. New Haven: Yale University Press. 2017, p.1. 
After all, the level of well-being enjoyed by societies nowadays depends essentially and jointly on the many ways the States and others international actors interact and cooperate in the international sphere. At the same time it makes the world more interdependent, the need for cooperation actions makes it more monitored if compared to the past, confirming a new power logic in the international relations.

From a southern perspective on international law, the reasons why decisions should be adopted in multilateral settings is related to the fact that they are more inclusive institutions in which developing countries have more space for action than in other organizations that currently suffer from a legitimacy deficit? ${ }^{7}$.

Environmental issues as a whole can only be met with satisfactory solutions if these are negotiated and regulated by the group of States that discusses interests using methods more efficient than diplomatic conferences, without disregarding the role played by the new actors in the international setting.

Global environmental issues have distinguishing characteristics: theyadhere to ecosystems, and not to political boundaries. Moreover, they have 'multiple interdependent causes and need coordinated forms of social organization and institutions for their effective resolution'8.

And, naturally, this new problematic had, and has its effects on the structure and dynamics of international law, where new areas of legal practice are consolidated seeking the renovation of the bases of the International Order, which is something required by this historical momentum,for the old bases cannot prevail in the construction of this new millennium.

Thus, new international environmental challenges call for the adoption of new and more inclusive perspectives whose clear objective is to allow the law to respond to the various global issues facing it in an effective and comprehensive manner'.

The North won its modernization and abundance through development that was unsustainable for the planet. The South expects to conquest better development indicators. The actors who seek prosperity

7 Concerning the BRICS perspective see ZIERO, Gabriel Webber. Looking for a BRICS perspective on international law. Revista de Direito Internacional, v. 12, n. 2 , p.304-323, 2015.

8 See ANDONOVA, Liliana B. \& MITCHELL, Ronald B.. The rescaling of global environmental politics. Annual Review of Environment and Resources, 35(1),p.255-282, 2010.

9 URIBE VARGAS, D. \& CÁRDENAS CASTAÑEDA, F. A..Derecho internacional ambiental . Bogotá: Fundación Universidad de Bogotá Jorge Tadeo Lozano, 2010, p.35. 
today cannot be asked to pay tomorrow for the costs of the old actors who secured their high indicators yesterday. However, this is not exactly how the process works.

The force of the North-South concept derives from major historical and political realities manifested in the post-World War II era. It is true that over time, the distinction between North and South has become less clear in an objective sense. But the fact remains that there are two sets of countries which are widely comprehended to consist of the developed and the developing, each set sharing certain broad characteristics and psychological affinities that suggests specific influences and approaches related to the contemporary international law.

\section{INTERNATIONAL ENVIRONMENTAL LAW}

The international environmental law is a new and dynamic area of law that has been developed on the evolution (and deficiencies) of the international law of the environment,and which is slowly becoming an independent 'branch' of the legal science, because it represents a distinct, specific set of rules and principles which address the relations of the subjects of the international law and the new international actors with the global sustainability agenda through the logic of building open, specific international regimes with the common purpose of protecting and managing the environment, and also committed to finding solutions.

The concept of international environmental law rises from the limitations of the international law of the environment, which is overly attached to international legal systems; the former presupposes a commitment to, and larger influence of environmental law rather than international law in its structuring and working logic,with an outside and beyond a northern perspective, incorporating a larger influence of the scientific and technological substrate underlying the complex global environmental issues.

So, the international environmental law is based on a legal system of interdisciplinary nature aimed at regulating the coexistence, cooperation, and interdependence relations, whether institutionalized or not, among the several international actors whose purpose is the international protection of the environment.

The international environmental law ends up being the result of processes and needs that would be the foundations of what some scholars 
call contemporary international law, in which historical collective concerns play a major role, justifying the need to make normative commitments that apply at a global level. However, this is not exactly the way the States face the risks and threats posed by complex issues permeating our daily life, which in one way or the other concern all States, including, of course, the issues on the international sustainability agenda as well as new issues relating to international peace and safety.

As it is known, the efforts to implement sustainable development models are centred in the rational use of natural resources and repositories, allowing everyone, as well as the future generations, to have access and enjoy their benefits. It is still a goal to be sought after, however inaccurate, no matter how much one endeavours to develop performance instruments, and which binds the obligations to do and not to do to the time factor, requiring short, medium, and long term actions.

Most of these efforts are still concentrated on the negotiation of future actions which are extremely influenced by the specific interests of North States, international organizations, and pressure groups. In this respect, the principles of international environmental law consolidated in the Rio Declaration reinforce the role played by the law to fight the influence of such interests, almost like an ethical requirement to develop a new understanding on how to work for a sustainable world. After all, this is a challenge to be faced by the international community with the active participation of others new South international actors ${ }^{10}$.

\subsection{Limitations of the Global North approach of international environmental law}

While still important the participation of the North to the making process of the international environmental law as a whole, especially in terms of norm creation, the operational efficacy of this way to understand the global problems and the new values of the international society are actually challenged, even because important Southern states pursue multilateral policies with other partners of the South, including nongovernmental organizations and independent experts.

Such facts revealed the need for the Global North approach of law to measure up to the challenges this postmodern society poses to it

10 SUSSKIND, L., MOOMAW, W., GALLAGHER, K..Transboundary environmental negotiation : new approaches to global cooperation. San Francisco: Jossey-Bass, 2002. 
by widening its international roles, which more and more possess a social, humanistic profile as it is concerned about the international protection of human rights and the new values of the international society to the establishment of principles for the sustainable development of all nations, contributing, this way, to the formulation of a new concept of safety, new peace requirements between States, a dynamic peace and continuous efforts to eliminate the still secular differences and disputes between States,as well as the promotion of a constructive dialog with new actors.

The sociology of international relations around the world advance in researches that stresses Southern sensibilities ${ }^{11}$, their hybridity and peripheral calling for attention to the heterogeneities and positionality struggles that influence the global governance.

The North-South differences are evident in many areas of the global environmental agenda and Southern states were then and today remain still sceptical about the North's push and compromise to impose imperatives on the own environmental agenda. From the southern perspective, ozone depletion and global climate change were products of industrialization and overconsumption in the North, but suddenly the priority to protect the environmental wasn't to come at the expenses of interests of the South ${ }^{12}$. In the debate over deforestation for example, southern negotiations, led by the Brazilians and Malaysians, resisted any incursion by the North into the principle of sovereignty over natural resources.

Despite important contributions by some States, the North collective contribution to the international environmental law making process and global governance in the longer term is more notable for nurturing agreement on ideas and principles about sustainable development than for its operational impact with projects on the ground.

However, it happens that this reality, with the advent of postmodernity, keeps changing continuously and at the same time starts revealing the dependencies and the limitations of the Global North approach oflaw in the perception of the scientific knowledge and in the difficulty to face such challenges.

Nowadays, international environmental law evolve to include

11 See KRISTENSEN, P.M. Southern sensibilities: advancing third wave sociology of international relations in the case of Brazil. In Journal of International Relations and Development, 2017p. 1-27. Available at: https://doi.org/10.1057/s41268-017-0107-z. Accesed: Oct.2, 2017.

12 WEISS, T., FORSYTHE, D., COATE, R., PEASE, K. The United Nations and Changing World Politics. Boulder: Perseus Books, 2017, p. 293. 
southern countries and to improve their participation in the international order and this movement necessarily reflects new underlying theoretical positions ${ }^{13}$ on the question of the relation of law to power as well as the understanding one has of the significance of the contribution of these countries in the global environmental governance agenda.

Thus, the purpose of the South approach of the international environmental law, in tune with the international relations, is to transform the relationships between the States and other government and governance structures, fostering cooperation and coordination amongst them so that all can contribute, even if in different ways, to the improvement of the environment and the dignity of life in a transgenerational perspective.

The South approach of the international environmental law seems to be a branch of law in which the use of the so-called soft law has become legitimate and much more effective owing to the flexible and malleable dynamics of these instruments. This approach suggests a more pragmatic, finalistic law that is concerned about the results, the achievement of the goals proposed. It is a law based on cooperation.

In this sense, it is believed that the result of relationships that require consensus between the stakeholders, even if not absolute, allows for greater cooperation to achieve the results expected, simply because it is not so strict, allowing for the adjustments necessary according to the changes resulting from uncertainty and risks. Therefore, the application of these instruments is believed to be very effective, mainly because the product of these interactions does not result from impositions, but, from consensuses and with a scientific basis, and yet, because the actors involved feel part of this governance process.

These interactions, acceptable to most southern states, are "more scientific and democratic". Creating the necessary global partnerships require meeting the challenges of cooperating effectively and for this is necessary to have a better understanding of the dynamic interplay of the forces and tensions that have given shape to the southern discourse and practice of international environmental law.

In fact, this functional and pragmatic southern perspective of the international environmental law is based on a mix of branches of law and other scientific contributions that coexist therein in a particular balance and intricate complexity. In this area of law the insertion of new actors

13 RAJAMANI, L.Differential Treatment in International Environmental Law. Oxford: Oxford University Press, 2006. 
in the multilateral normative and political processes and the contribution given by the scientific knowledge reinforce the role of soft law as the major tool to aid the adaptation of the traditional international law to the new challenges facing the contemporary society, given the impossibility of moving forward in certain fields using binding rules ${ }^{14}$.

This is why facing it turns out to be a complex challenge that requires new solutions devised also by the southern perspective.

\section{GLOBAL ENVIRONMENTAL GOVERNANCE}

Many of the environmental challenges the world is facing are transboundary and must be addressed through joint actions. The global environmental governance system provides an important foundation for addressing these types of common environmental challenges, and the last decades have witnessed a rapid development of the international system of environmental governance. It is manifested in a series of major UNconferences and as much as more than 1100 international environmental treaties.

There is a diversity of perspectives and interpretations of the term governance; it implies a focus on systems of governing, means for 'authoritatively allocating resources and exercising control and coordination ${ }^{15}$, in which states are not necessarily the only or most significant actors.

Global environmental governance has been defined as "the norms, rules, laws, expectation, and structures established to guide behaviour according to a set of public purposes ${ }^{16}$. Rather than seeing government and governance as necessarily opposite, this interpretation suggests a continuum of systems of governing, in which state, subnational and local governments and private actors play a variety of roles. In this sense, governance 'has become one of the key themes in global environmental politics ${ }^{17}$.

However, the traditional international way of facing global issues,

14 REI, F.C.F. \& GRANZIERA, M.. Direito ambiental internacional: novos olhares para a ciência do direito. In REI, F. \& GRANZIERA, M.L. 40 anos das Conferências das Nações Unidas sobre Meio Ambiente: reflexões e desafios do direito ambiental internacional. São Paulo: Atlas, 2015, p. 153.

15 RHODES, R.. The new governance: governing without government. Political Studies, XLIV, p.653, 1996.

16 ANDONOVA, Liliana B. \& MITCHELL, Ronald B.. The rescaling of global environmental politics. Annual Review of Environment and Resources, 35(1), p.257, 2010.

17 PATERSON, M., HUMPHREYS, D. \& PETTIFORD, L.. Conceptualizing global environmental governance: from interstate regimes to counter-hegemonic struggles. Global Environmental Politics, 3(2), p.1, 2003. 
still made official by means of consensual agreements signed between sovereign States, is increasingly and directly influenced by the internal and external interests of such States, particularly within a context of crescent, and mainly economic, interdependency ${ }^{18}$.

Usually, these interests do not combine, in time, with the requirements and schedules to face global environmental issues, because while they have a short term horizon or present a mainly political-economic nature, the global environmental issues require long term actions and a much broader view. Furthermore, as good example of complex global issues, climate change reach beyond the state barriers and borders defined by men,either because they constitute an ecological continuum that extends both within the spaces submitted to the States' sovereignty and beyond that, or because the actual impacts of such environmental issues are felt at infra-national levels of government, namely at the local urban structures in the South.

As a consequence, the complexity for the formulation of a traditional international response, specially by means of international legal regimes, and the increasing and challenging need for practical and pragmatic actions to face global environmental issues have progressively legitimated the rising of new forms of authority.

Framed as problems of collective action between sovereign states, within traditional accounts of global environmental politics, the notion of the state as the primary arena of political power is changing and there have been new analyses of the changing nature of the state and its sovereignty.

Thus, we hear about a new way of facing these challenges: through global environmental governance ${ }^{19}$.

Moving on with this multilateral response, less rigid and structured, involves the discussion and action by multiple actors, because for the implementation of the global environmental governance the cooperation and negotiation require wider participation to build the possible consensus ${ }^{20}$.

18 LEIS, H.R. \& VIOLA, E..América del Sur en el mundo de las democracias de mercado. Rosario: Homo Sapiens Ediciones, 2008, p.196.

19 See REED, M.G., BRUYNEEL, S.. Rescaling environmental governance, rethinking the state: a three-dimensional review. Progress in Human Geography, vol. 34, 5, p.649, 2010. According the authors, 'as environmental problems cross borders spatially (affecting multiple jurisdictions) and temporally (posing risks for the present and for future generations), they necessitate cooperation among nations and stakeholder groups in a form of global environmental governance.'

20 REI, F.C.F. \& GRANZIERA, M.. Direito ambiental internacional: novos olhares para a ciência do direito. In REI, F. \& GRANZIERA, M.L. 40 anos das Conferências das Nações Unidas sobre Meio 
This discussion and action is something less familiar, messier, more diffuse and dynamic- in a word, experimental ${ }^{21}$. This action reveal show cities, countries, provinces, regions, civil society, academia and corporations are responding to climate change irrespective of the officialUN-sponsored negotiations and treaties.

It is therefore through global environmental governance that different forms, experiences, and levels of assessment of environmental issues start to coexist in a complementary fashion, rather than conflicting with each other. Good examples of this environmental governance are focused on the ways in which, through different networks, the rescaling of environmental problems and their solutions has taken place between territorially delimited arenas of governance.

\subsection{Global environmental governance and the southern scientific expertise}

The participation, for instance, of the southern scientific community offers the potential to influence the decision-making process at international forums, besides conferring them an international legitimacy. It is true that exists knowledge divide between North and South regarding environmental issues, but, from a historical perspective, it can be seen as just a phase of the scientific development process.

Part of the responsibility for the recent strengthening the scientific community in the South lies in the hands of developing countries themselves who prioritized investment in science. But the southern efforts weren't enough. The role for bi- and multilateral aid agencies and Northern and international research programs in building this capacity was essential.

There was a time when science was carried out by inspired individuals, developing theories or designing experiments that could only be done on a table top of the North. Those days are long gone. Much of today's science involves huge multicultural teams working to timescales of years or even decades. . In a world such as this, the ethical dimension of scientific knowledge comes to the fore, and scientific governance becomes key.

There are a number of scientific advisory processes at the global level through which southern scientists are invited to give advice Ambiente: reflexões e desafios do direito ambiental internacional.São Paulo: Atlas, 2015, p. 155.

21 HOFFMANN, M.J..Climate governance at the crossroads: experimenting with a global response after Kyoto. New York: Oxford University Press, 2011, p.5. 
on environmental issues. Scientific expertise from the South is sought in intergovernmental bodies, in ad hoc expert groups to various conventions, in bodies that develop technical standards and global assessments on the state of environmental knowledge, or in capacity building and multilateral aid projects.

One of the most important actor in this field probably is the IPCC. The Intergovernmental Panel on Climate Change (IPCC) is the international body for assessing the science related to climate change. The IPCC was set up in 1988 by the World Meteorological Organization (WMO) and United Nations Environment Programme (UNEP) to provide policy makers with regular assessments of the scientific basis of climate change, its impacts and future risks, and options for adaptation and mitigation. Actually, the Chair of the IPCC ${ }^{22}$ is from the Republic of Korea, Hoesung Lee, the vicechairs (in a total of three) are from Brazil, Thelma Krug, and Mali, Youba Sokona, a Co-Chair of the Working Group I is from China, Panmao Zhai, a Co-Chair of the Working Group II is from South Africa, Debra Roberts, a Co-Chair of the Working Group III is from India, Priyadarshi R. Shukla, and finally a Co-Chair of Task Force Bureau is from Peru, Eduardo Calvo Buendía.

It suggests that there isn't a knowledge divide between the North and the South. The IPCC results from the eventual difference in accumulated scientific knowledge about the two regions and their current peculiar capacities for generating new knowledge. In this sense (1) issues of the South will be visible on the global governance agenda, (2) globalized knowledge generated in other ecological zones and socioeconomic settings is representative for conditions in the South, and (3) as a result, the South is able to participate on equal terms in global governance.

IPCC assessments provide a scientific basis for governments at all levels to develop climate related policies, and they underlie negotiations at the UN Climate Conference - the United Nations Framework Convention on Climate Change (UNFCC). The assessments are policy-relevant but not policy-prescriptive: they may present projections of future climate change based on different scenarios and the risks that climate change poses and discuss the implications of response options, but they do not tell policy makers what actions to take.

Developing country scientists have welcomed the reports of IPCC, which they said backed their own observations. But they do not 
need the Panel to tell them that the weather is changing ${ }^{23}$.

In this context, one cannot ignore the importance of the role the these actors of the international society have been playing in the structure thereof, many of them sitting at Conferences of the Parties of Multilateral Treaties in the capacity of observers, developing a series of initiatives, many of them in network, providing rigorous and balanced scientific information to decision-makers.

These strong connections of the international environmental law with the participation of new public and private international actors from the South, and with the evolution of the scientific knowledge, which is the basis for some international regimes, influence the transformation of the traditional concept of sovereignty by including on it different perspectives, which has allowed the redefinition thereof. Sovereignty can no longer be categorically understood as the unlimited power exercised by a State over the natural resources within its territory. This power can be limited and, in many cases, made relative, when it goes against the common interest of the international society.

For this reason, the international environmental law is blamed by many legal minds to be extremely linked to the reality of the facts, to real politics, and too much subordinated to scientific knowledge and ecological laws ${ }^{24}$.

The global environmental issues and its consequences cannot be considered a problem of the North alone, but rather a collective problem for the international community, since the North and the South are ultimately part of the same physical and social whole.

Integrate different types of knowledge is inherently complex. There is no single optimum approach for integrating local and scientific knowledge and encourage a shift in science. Any serious approach to addressing the global polices should consider not only the goal of making global environmental governance more equitable and more broadly knowledge-based, but also the deeper underlying issue of what it means for people to be involved in the generation of knowledge about their own realities.

23 See THE GUARDIAN. Climate change will hit poor countries hardest, study shows. Friday 27 September 2013. Available at: https://www.theguardian.com/global-development/2013/sep/27/climatechange-poor-countries-ipcc. Access: Oct. 1, 2017, when SaleemulHuq, director of the International Centre for Climate Change and Development, based in Dhaka, said:The IPCC makes the case that climate change is real and happening much more strongly than before. We are already seeing the effects of climate change in Bangladesh and across south Asia. It's not news to us. Most developing countries are facing climate change now. They do not need the IPCC to tell them that the weather is changing.

24 LITFIN, K.T.. Environment, Wealth and Authority: global climate change and emerging modes of legitimation. InternationalStudiesReview, vol.2, 2, p.119-148, 2000. 


\subsection{Environmental paradiplomacy: the influence of the South}

The 1980s saw the development of a concept to describe the international relations conducted by subnational, regional, local and nonState actors; the participation of such actors in the international arena was named paradiplomacy.

The phenomenon has grown both quantitatively and qualitatively since the early nineties in Brazil, thanks to structural changes in the world order and domestic political and economic transformations. The end of the Cold War coincided with the implementation of new external and internal patterns of economic integration, the re-democratization of the Brazilian political and civil society, as well as the promulgation of the new 1988 Constitution. In such a context, paradiplomacy of subnational entities in Brazil has significantly developed since the late 1980s thanks to the decentralization architecture of the Brazilian federation approved in the new constitutional system ${ }^{25}$. It is true that subnational entities have also had their paradiplomatic activities activated and facilitated in other federative systems in Latino America, such as in the Argentina, Ecuador and Mexico.

The participation of global corporations, NGOs, native peoples and subnational governments in the multilateral negotiation processes has long been promoting the extent and reach of the international debate on the role played by the new international actors ${ }^{26}$. The insertion of these new actors in the international society, a pillar for the structuring of the subjects of the international environmental law, is directly associated with two remarkable phenomena of the 20th century: the globalization process and the rising of complex global environmental issues ${ }^{27}$.

As described, since the 1990s, a number of local and regional governments around the world have started to engage in a real international

\footnotetext{
25 RIBEIRO, M. C. T.. Globalização e novos atores: as cidades brasileiras e o desenvolvimento da paradiplomacia.Unpublished Master's degree dissertation, Federal University of Bahia, Salvador, BA, Brazil, 2008.

26 See KeOHANE, R. \& Nye Jr, J.S. .Transnational Relations and World Politics. Cambridge: Harvard University Press, 1971. And RISSE-KAPPEN, T.. Bringing Transnational Relations Back. In Non-State Actors, Domestic Structures and International Institutions. Cambridge: Cambridge University Press, 1995.

27 See FARIAS, V., REI, F. Reflexos jurídicos da governança global subnacional: a paradiplomacia e o direito internacional: desafio ou acomodação. Revista de Direito Internacional, Brasília, v.13, n. 1, 2016 p. 322-323.
} 
or 'paradiplomatic' climate agenda. While the multilevel governance approach has advanced the examination of the actors and levels involved in climate governance, there is within this body of literature a limited consideration of the legal capacity of non-state actors to act across scales $^{28}$.

The globalization phenomenon brought consequences along with it that have changed the international scenario; so currently, the social, environmental, economic and political issues reach beyond State boundaries, and they are no longer issues tackled solely at local level. In addition, the traditional way of solving problems at international level isn't enough in the context of sustainable development proposed by several international agencies, such as for instance, the climate change regime. The environmental problems have become cross-border issues, reaching beyond national territories, affecting other States, and, especially, the world as a whole.

But, impacts of climate change will have a disproportional negative impact on developing countries ${ }^{29}$. Climate change will exacerbate problems related rapid population growth, existing poverty and a heavy reliance on agriculture and the environment. And, it must be recognized that the South have more limited capacity to cope with the problems caused by climate change. Such situation brings to this setting other actors that are claiming for a global south voice and participation in the solution of the problems that affects them as well.

These actors, however lacking the typical elements of sovereignty and excluded in the international legal order, create new structures to face the problems and slowly gain the society's voluntary legitimacy stemming from the acknowledgement that to effectively face global environmental issues we need cooperate and coordinate action by governance systems based on several levels, opening an alternative narrative and comprised by various state, infra-state, and non-governmental actors, where everyone performs a range of roles ${ }^{30}$.

Thus, subnational governments, corporations, and others

28 SETZER, J.. Testing the Boundaries of Subnational Diplomacy: The International Climate Action of Local and Regional Governments. Transnational Environmental Law, 4 (02), p.319, 2015.

29 STERN, N..The economics of climate change. Cambridge University Press, 2007. Available at: http://www.hmtreasury.gov.uk/independent_reviews/stern_review_economics_climate_change/stern review_report.cfm. Accessed: Oct. 5, 2017.

30 REI, F.C.F. \& GRANZIERA, M.. Direito ambiental internacional: novos olhares para a ciência do direito. In REI, F. \& GRANZIERA, M.L. 40 anos das Conferências das Nações Unidas sobre Meio Ambiente: reflexões e desafios do direito ambiental internacional.São Paulo: Atlas, 2015, p. 155. 
have begun to see themselves as authoritative actors in general, and this translates into an enhanced inclination to see themselves as authoritative actors in climate change ${ }^{31}$.

As the climate science keeps evolving, the southern aspects of climate changes are reinforced, because the seriousness of its impacts is already being felt at all levels of the developing countries, and under different environmental, social, economic, and political nuances, with inaccurate adaptation scenarios.

In this context, it is impossible to ignore the rising of movements for 'climate justice' which are characterized by the fight against the more predictable and concrete risks of climate changes, given that, although everyone is subject to the risks, they end up charging a higher price from certain classes of the population than others because of their specific vulnerable conditions. In fact, climate justice links human rights and development to achieve a human-centred approach, safeguarding the rights of the most vulnerable people from the South and sharing the burdens and benefits of climate change and its impacts equitably and fairly. Climate justice is informed by science, responds to science and acknowledges the need for equitable stewardship of the world's resources.

This is why facing it turns out to be a complex challenge that requires new solutions devised by the scientific thought, including the law.

Seen as a field where new paths for the international environmental law can be found, the international climate change regime, through the Paris Agreement, has just taken a great leap towards explicitly recognizing the importance of the role played by the new international actors to face this issue, as well as the relevance of the subnational and local dimensions. After all, it is no longer acceptable these days to defend solely the idea that a climate regime is defined by means of an international regime centred on a consensual agreement of all participating States. This way, the increasing participation of the subnational states in a multilateral regime, even if in parallel to the action of national states, allows to conclude that both the actors involved in the multilateral negotiations and the scales involved in the international law have been extended.

Despite being formally created as mechanisms for exchanging information, techniques, practices and experiences in the measures

31 See HOFFMANN, M.J..Climate governance at the crossroads: experimenting with a global response after Kyoto. New York: Oxford University Press, 2011, p.61. 
adopted to face climate changes, the participation of subnational states in a multilateral regime, principally by networks end up playing a political role, particularly when they act in a coordinated way in the international negotiation sphere ${ }^{32}$. This is the case of The Network of Regional Governments for Sustainable Development (nrg4SD).

The $n$ rg4SD is an international organization representing regional and associations of regional governments at the global level, being that $2 / 3$ of the members of nrg4SD are regional governments from the South.

The network promotes understanding, collaboration and partnerships in sustainable development and seeks greater international recognition of the importance of the contribution that regions make to sustainable development. To influence the climate change negotiation process, nrg4SD has been working individually and with other subnational governments networks ${ }^{33}$, such as The Climate Group, the Local Governments for Sustainability (ICLEI) and the United Cities and Local Governments (UCLG). This wording constitutes a clear message for the regional level to capitalize on, in order to keep turning the citizens growing awareness of climate matters into daily action. It also represents an unprecedented context for subnational governments to contribute to adapting international climate change governance to modern times ${ }^{34}$. The story of nrg4SD is a story of regional governments showing courage and leadership, conscious that the success of international agreements depends partly on the effectiveness with which they exercise their competencies and their boldness in the face of pre-established conditions ${ }^{35}$.

Although the vast majority of internationalists defend the idea that the State is still the main actor in the international society, the truth is that, given the level of technicality necessary to tackle environmental issues, as well as the interdependence involving issues and monitoring of complex demands, the participation of the new international actors in the regimes is unquestionable ${ }^{36}$.

32 BULKELEY, H.. Reconfiguring environmental governance: towards a politics of scales and networks. PoliticalGeography, 24, p.875-902, 2005.

33 See REI, F., SETZER, J., CUNHA, K.. A Rio+20 e o quadro institucional pelo desenvolvimento sustentável: o papel dos governos subnacionais na governança ambiental global. Revista de Direito Internacional, Brasília, v. 9, n. 3, 2012, p. 136.

34 REI, F.; CUNHA, K..The environmental paradiplomacy in a new international governance, 2011. Available at http://wsforum.org/. Accessed: Oct.7, 2017.

35 VERA, Natalia..The story of nrg4SD, 2017. Available at: http://www.nrg4sd.org/story-nrg4sd-natalia-vera/. Accessed: Oct.1, 2017.

36 URIBE VARGAS, D. \& CÁRDENAS CASTAÑEDA, F. A..Derecho internacional ambiental. Bogotá: Fundación Universidad de Bogotá Jorge Tadeo Lozano, 2010, p. 85. 
The power of central government to develop and implement sustainable policies in a top-down manner has decreased in the last 20 years, leading to increasingly diffuse policymaking structures and processes stratified across subnational (and supranational) levels of government. During this period, the networks of cities and regional governments responding sustainable problems have multiplied. Fifteen years ago the political purpose was to be recognized as a relevant actor and perhaps as a new subject of international law. Today, sub national governments have the challenge of executing public policies in many sustainable issues for the administration of their territories.

And, the agreements and Protocols of Intentions entered by a subnational government with other governments or international organizations, although not legally binding, are frequently used to create a loose and adaptable framework in which information, ideas, and resources are shared ${ }^{37}$. They are non-binding as a legal matter, but, at least from the point of view of many regulators, highly effective and far more flexible. It also contributes more generally to research on global environmental governance, offering new theoretical insights, including southern perceptions, on the roles of subnational governments and the changing relationships between different levels of government in national and international policymaking.

\section{Final considerations}

The purpose of this article when it discusses the challenges and the southern approaches brought to global governance by international environmental law gets mixed with the addressing of the challenges facing the legal science in harmony with the others sciences to deal with the complex environmental issues of the $21^{\text {st }}$ century. Thinking of a successful international environmental regulation is talking about an effort to understand the need for the instrumental law to comply with its role to solve wide, complex issues that are typical of the construction of a sustainable society, which are inherent thereto and the reason itself for its formulation and existence. In other words, it is assuming the need to develop new looks, which see not only a law of principle and rules but start

37 As noted by RAUSTIALA (2002), apud SETZER, J.. Environmental paradiplomacy: the engagement of the Brazilian state of São Paulo in international environmental relations. PhD diss., London School of Economics and Political Science, 2013, p. 124. 
seeing a law of obligations, commitment, and actions that yield results.

So, it seems to be acceptable and legitimate to acknowledge a more and more consolidated basis for the so-called international environmental law,with its own regulatory characteristics, which manages to collaborate to the movement of knowledge and efforts to face new issues that call for quick, new, and effective solutions.

This movement that makes way for the participation of new actors from the South- whether they be individuals, scientific societies, NGOs, indigenous or aboriginal peoples, multinational corporations, subnational, local government associations etc. -, together with the central States, in the processes for preparation and application of the rules will allow the continuity of the work of building awareness about common subject matters of the international environmental law, in the path to build a new legitimacy pact, centred on global environmental governance.

In other words, the international environmental law permits to the international law to reformulate concepts and proceedings in order to face the complex environmental problems, accepting a different vision of the international regulation in harmony with the scientific and technology knowledge.

The purpose of the South approach of the international environmental law, in tune with the international relations, is to transform the relationships between the States and other government and governance structures, fostering cooperation and coordination amongst them so that all can contribute, even if in different ways, to the improvement of the environment and the dignity of life in a transgenerational perspective.

In fact, the contribution, the influence of the South in the international environmental law is completely other than against its historical role of "dominated": if historically the international law served the interests of the North rather than the South, the international environmental law approaches can be used advantageously by the South to resist the old idea of the positivism of the strong. This functional and pragmatic southern perspective of the international environmental law is based on a mix of branches of law and other scientific contributions that coexist therein in a particular balance and intricate complexity.

Thus, the southern influence in the international environmental law and in the global environmental governance suggest a more pragmatic and finalistic approaches that is concerned about the results, the achievement of the goals proposed. It is a contribution to a law and governance inspired 
on a multilateral cooperation.

\section{REFERENCES}

ANDONOVA, Liliana B.\&MITCHELL, Ronald B..The rescaling of global environmental politics. Annual Review of Environment and Resources, 35(1), p.255-282, 2010.

BARBER, Benjamin. Cool Cities: urban sovereignty and the fix for global warming. New Haven: Yale University Press, 2017.

BECK, Ulrich..Sociedade de risco: rumo a uma outra modernidade. São Paulo: Editora 34, 2010.

BUANI, C.. A justiça de transição: ápice da internacionalização do direito? Revista de Direito Internacional, Brasília, v. 9, n. 4, 2012, p. 123-151.

BULKELEY, H.. Reconfiguring environmental governance: towards a politics of scales and networks. Political Geography, 24, p. 875-902, 2005.

FARIAS, V., REI, F. Reflexos jurídicos da governança global subnacional: a paradiplomacia e o direito internacional: desafio ou acomodação. Revista de Direito Internacional, Brasília, v.13, n. 1, 2016 p. 322-323.

HOFFMANN, M.J. Climate governance at the crossroads: experimenting with a global response after Kyoto. New York: Oxford University Press, 2011.

KEOHANE, R. \&NYE JR, J.S.. Transnational Relations and World Politics. Cambridge: Harvard University Press, 1971.

KRISTENSEN, P.M. Southern sensibilities: advancing third wave sociology of international relations in the case of Brazil. In Journal of International Relations and Development, p. 1-27. 2017. Available at: https://doi.org/10.1057/s41268-017-0107-z

LEIS, H.R. \&VIOLA, E..América del Sur en el mundo de las democracias de mercado. Rosario: Homo Sapiens Ediciones, 2008.

LITFIN, K.T.. Environment, Wealth and Authority: global climate change and emerging modes of legitimation. International Studies Review, vol.2, 2, p.119-148, 2000.

PATERSON, M., HUMPHREYS, D.\&PETTIFORD, L.. Conceptualizing global environmental governance: from interstate regimes to counter- 
hegemonic struggles. Global Environmental Politics, 3(2), p. 1-10, 2003.

RAJAMANI, L. Differential Treatment in International Environmental Law. Oxford: Oxford University Press, 2006.

REED, M.G., BRUYNEEL, S.. Rescaling environmental governance, rethinking the state: a three-dimensional review. Progress in Human Geography, vol. 34, 5, p. 646-653, 2010.

REI, F.; CUNHA, K..The environmental paradiplomacy in a new international governance. 2011. Available at: http://wsforum.org/. Accessed: Oct. 5, 2017.

REI, F., SETZER, J., CUNHA, K..A Rio+20 e o quadro institucional pelo desenvolvimento sustentável: o papel dos governos subnacionais na governança ambiental global. Revista de Direito Internacional, Brasília, v. 9, n. 3, 2012, p. 129-140.

REI,F.C.F..The Rio+20 in question. Revista Brasileira de Bioenergia, 14, p. 44-52, 2012.

REI, F.C.F.\&GRANZIERA, M.L..Direito ambiental internacional: novos olhares para a ciência do direito. In: REI, F.\& GRANZIERA, M.L.40 anos das Conferências das Nações Unidas sobre Meio Ambiente: reflexões e desafios do direito ambiental internacional.São Paulo: Atlas, 2015.

RIBEIRO, M. C. T.. Globalização e novos atores: as cidades brasileiras e o desenvolvimento da paradiplomacia. Unpublished Master's degree dissertation, Federal University of Bahia, Salvador, BA, Brazil, 2008.

RISSE-KAPPEN, T.. Bringing Transnational Relations Back. In Non-State Actors, Domestic Structures and International Institutions. Cambridge: Cambridge University Press, 1995.

Rhodes, R.. The new governance: governing without government. Political Studies, XLIV, p.652-667,1996.

SETZER, J..Environmental paradiplomacy: the engagement of the Brazilian stateof São Paulo in international environmental relations. $\mathrm{PhD}$ diss.,London School of Economics and Political Science, 2013.

SETZER, J.. Testing the Boundaries of Subnational Diplomacy: The International Climate Action of Local and Regional Governments. Transnational Environmental Law, 4 (02), p.319-337, 2015. 
STERN, N..The economics of climate change,2007.Cambridge University Press. Available at: http://www.hmtreasury.gov.uk/independent_reviews/ stern_review_economics_climate_change/stern_review_report.cfm. Accessed: Oct. 5, 2017.

SUSSKIND, L.. Environmental Diplomacy. Oxford University Press, 1995.

SUSSKIND, L.,MOOMAW, W.,GALLAGHER, K..Transboundary environmental negotiation: new approaches to global cooperation. San Francisco:Jossey-Bass, 2002.

THE GUARDIAN.Climate change will hit poor countries hardest, study shows.Friday 27 September 201309.01 BST. Available at:https://www. theguardian.com/global-development/2013/sep/27/climate-change-poorcountries-ipcc. Access: Oct. 8, 2017.

URIBE VARGAS, D. \&CÁRDENAS CASTAÑEDA, F. A..Derecho internacional ambiental. Bogotá: Fundación Universidad de Bogotá Jorge Tadeo Lozano, 2010.

VERA, Natalia. The story of $n r g 4 S D, 2017$. Available at: http://www. nrg4sd.org/story-nrg4sd-natalia-vera/.Accessed: Oct. 2, 2017.

WEISS, T., FORSYTHE, D., COATE, R., PEASE, K. The United Nations and Changing World Politics. Boulder: Perseus Books, 2017.

ZIERO, Gabriel Webber. Looking for a BRICS perspective on international law. Revista de DireitoInternacional, v. 12, n. 2, p.304-323, 2015.

Artigo recebido em: 06/03/2018.

Artigo aceito em: 25/05/2018.

\section{Como citar este artigo (ABNT):}

REI, F. C. F. INTERNATIONAL ENVIRONMENTAL LAW AND GLOBAL ENVIRONMENTAL GOVERNANCE: SOUTHERN INFLUENCES. Veredas do Direito, Belo Horizonte, v. 15, n. 32, p. $143-$ 165, mai./ago. 2018. Disponível em: <http://www.domhelder.edu.br/ revista/index.php/veredas/article/view/1257>. Acesso em: dia mês. ano. 